\title{
On Arthur Dimmesdale's Double Personalities as Revealed in Hawthorne's The Scarlet Letter
}

\author{
Yanchun Chen $^{1}$ \\ ${ }^{1}$ Guangdong University of Science and Technology, Dongguan, Guangdong, China \\ Correspondence: Yanchun Chen, Guangdong University of Science and Technology, Dongguan, Guangdong, \\ China. E-mail: 710144484@qq.com
}

$\begin{array}{lc}\text { Received: August 4, } 2017 \quad \text { Accepted: August 20, } 2017 \quad \text { Online Published: August 30, } 2017 \\ \text { doi:10.5539/ells.v7n3p85 } & \text { URL: http://doi.org/10.5539/ells.v7n3p85 }\end{array}$

\begin{abstract}
This paper focuses on the analysis of the double personalities of Arthur Dimmesdale, a protagonist in The Scarlet Letter. Firstly, it briefly introduces the fame of Nathaniel Hawthorne in American literature and the content of The Scarlet Letter. Then, it mainly analyzes Arthur Dimmesdale's double personalities. After that, it studies the factors in shaping Arthur Dimmesdale's double personalities. The paper aims to help people better understand such a hypocritical person and a corrupt society, making them think of their own personalities. It comes to an end that without a healthy personality, one person absolutely comes to his/her death guiltily, even though he/she is learned.
\end{abstract}

Keywords: double personalities, contorted soul, corrupt society, death

\section{Introduction}

One cannot help but be overwhelmed by the greatness of Nathaniel Hawthorne, whose genius is most explicitly demonstrated in his books, especially in The Scarlet Letter, which has swept over two hundred years and which seems greater every time when it is read. Hawthorne is accorded due recognition by his contemporary James Russell Lowell in the latter's A Fable for Critics. It is Hawthorne's ability to make a story exist in its own right and at the same time appears as a moral symbol that most influences the work of Herman Melville, as Melville calls his friend as the largest brain with the largest heart (Wu, 1990, p. 199). The Jamesian psychological realism may have taken its cue from Hawthorne's soul-searching works. Other realistic writers like William Dean Howells learn to use Hawthorne's fiction as the benchmark for their novel-writing practice. In the 20th century William Faulkner and some Gothic novelists clearly show their indebtedness to Hawthorne. Henry James points out that Hawthorne's work will remain and among the men of imagination he will always have his niche (Chang, 2003, p. 79). Hawthorne has singular power to reveal the black vision which exists in the human heart. He reveals the depth of his concern with the dark side of Puritanism, which is epitomized in Arthur Dimmesdale. Time will not diminish Hawthorne's contribution and he will deserve the reputation at all times.

The Scarlet Letter is a book mainly about sin and stigma. Hester Prynne, Roger Chillingworth's wife, has not controlled her feelings and has made love with Arthur Dimmesdale - an excellent young clerk, by which she betrays the strict doctrine of Puritanism and for that, she, an adulteress, has to wear a scarlet letter "A" on her breast. The rigorous moral discipline is enforced by this way. Roger Chillingworth often says that for the art's sake, he must search this matter to the bottom (Cao, 2004, p. 29), and the end of Chillingworth, when it comes, is also tragic enough. Arthur Dimmesdale is a talented minister who always utters eloquent and reasonable sermons which charm his audiences. After committing adultery with Hester Prynne, he covers his sin and leaves her lover to bear the suffering at first. For seven years, the fire of sin and humiliation has been on the increase ever since and he has nearly been suffocated. Finally, he unveils the truth in his heart and dies. Hawthorne in a sense whips Arthur Dimmesdale into critical shape-Arthur Dimmesdale dying of his double personalities. Thus, Hawthorne gradually unveils the corruption of the society and the contortion of the soul.

\section{Arthur Dimmesdale's Double Personalities}

\subsection{Gifted Preacher Being Respectable}

Hawthorne makes great efforts to portray a respectable preacher. He sets Arthur Dimmesdale into the stage. With the description of Arthur Dimmesdale's sermons and the reaction of the people, the impression of Arthur 
Dimmesdale being a respectable figure is gradually formed.

Arthur Dimmesdale is a young clergyman who has come from one of the great English universities, bringing all the learning of the age into Massachusetts. His eloquence and religious fervor has already gained him high eminence in his profession. He is a person of very striking appearance, with a white, lofty, and impending brow, large, brown, melancholy eyes, and a mouth which, unless he forcibly compresses it, is apt to be tremulous, expressing both nervous senility and a vast power of self-restraint. This displays the talent of Arthur Dimmesdale. There is no room for doubt that he is a smart person who possesses a sharp intellect. His power will surely be established and increase over time. To the people of Massachusetts, who possess by hereditary right, the quality of reverence, Arthur Dimmesdale is admirable and his strength is angelic. One autumnal matron names the young minister as the Reverend Master Dimmesdale on the day when Hester Prynne is brought to the Market Place. Thus far, Arthur Dimmesdale has not appeared, yet he attracts people's curiosity and awe. The time when Arthur Dimmesdale comes out, Governor Bellingham calls him "Good Master Dimmesdale" and urges Dimmesdale to exhort her (Hester) to confess the truth. Taking great pains, Hawthorne paints Arthur Dimmesdale in the shape of an ineffably gifted preacher. Arthur Dimmesdale's sermons are so attractive that thousands of people are moved. His talent is not in question.

Under the sermon of Bellingham, Arthur Dimmesdale's voice tremulously sweet, rich and deep. It is so powerful the minister's appeal that the people could not believe but that Hester Prynne would speak out the guilty name. Arthur Dimmesdale has achieved a brilliant popularity in his sacred office while he is suffering under bodily disease. The aged members of his flock hope that their old bones should be buried close to their young pastor's holy grave. On the Election Day, Arthur Dimmesdale's ineffable talent comes to its peak. His vocal organ is in itself a rich endowment and attracts a listener comprehending nothing of the language in which the preacher spoke. Arthur Dimmesdale's preaching which is regarded as a tongue native to the human heart that educates people at every moment. As the author points out that it is this profound and continual under tone that gives the clergyman his most appropriate power.

\subsection{Selfish Man Being Irresponsible}

Thought Arthur Dimmesdale is a talented minister, yet he epitomizes the essence of irresponsibility, cowardice and obduracy. Arthur Dimmesdale's irresponsibility is the mother of his evil which affects both his physical and spiritual heart. Readers may not blame his aberrant behavior which leads him to make love with Hester Prynne for the sake of the nature of human beings. All need sex, yet all have to undertake their duties. Arthur Dimmesdale has to share the alienation and isolation coming from society with his lover when she is put on the market-place. He is a man. What he has to do is to carry out his obligation - a man's obligation. Shame is on him. The sermon given to Hester Prynne further displays his irresponsibility. He asks Hester Prynne to believe him, though he (sinner) was to step down from a high place, and stand there beside her. He even considers it as it were to compel the sinner. Why not bravely tell the truth? Thus he can get the mercy. In order to cover his sin, he murmurs that she will not speak so that he can interrupt Hester.

Arthur Dimmesdale has not visited Hester and Pearl, his daughter, for two years. The time when Hester Prynne struggles to get the right to continue to raise Pearl, Arthur Dimmesdale even regards Hester as sinful woman and Pearl as an infant immorality. From then on, Arthur Dimmesdale is suffering from this and his behavior becomes irresponsible. Step by step, his irresponsibility becomes the devil occurring in his heart, which is always torturing him to death. What he expects to do is to leave for Heaven. He says to himself that he could be well content, that his labors, and his sorrows, and his sins, and his pains should shortly end with him, and what is earthly of them be buried in his grave, and the spiritual go with him to his eternal state, rather than that you should put your skill to the proof on his behalf. Pearl requests him to stand together with Hester and her, but he refuses time and time again. God should blame him! Being a father, in the condition of the simple demands from his daughter, he even shuffles it off. So what a father he is! He is only an indifferent wolf. For seven years, he has not helped Hester and his daughter. In the forest, Hester advises they go back to their native land, but Arthur Dimmesdale does not agree with her. For seven years, he has done nothing for Hester and Pearl. His refusal exposes his irresponsibility indeed which is unforgivable and unpardonable.

\subsection{Bad Guy Being Coward}

Arthur Dimmesdale's cowardice derives from his irresponsibility and haunts over his whole short life. When he gives a sermon to Hester Prynne, his voice is tremulously broken. In the situation where another voice from the crowd interrogates Hester to give her child a father, Arthur Dimmesdale murmurs that she will not speak deliberately to hold back Hester's words. At this time, he is leaning over the balcony, with his hand upon his heart. This is the symptom of his cowardice. In The Scarlet Letter, there are many places where the author 
mentions this. They strongly cite the cowardice of Arthur Dimmesdale and reveal the dark side of his heart. Good Mr. Wilson fears the woman who had no better thought than to make a mountebank of her child, however, Arthur Dimmesdale startles and utters to himself. Arthur Dimmesdale is afraid that if Pearl is to be separated from Hester, the truth will come out. At that time, his sin will be exposed to the people. That is not what he wants, which will deepen his anxiety. Chattering with Roger Chillingworth, he hopes that his labors and his sorrows, and his sins and his pains shall shortly end with him. As a matter of fact, due to his cowardice, he is suffering and he deserves it. He shall know that he can get nowhere. Only the truth can release him. The interrogation of himself embodies his cowardice.

There is another piece of evidence that shows Arthur Dimmesdale's cowardice. The time when Roger Chillingworth tries to touch Arthur Dimmesdale's heart, Dimmesdale says no to him timidly, which reflects his cowardice too. The stigma has been deeply branded in his heart and caused his cowardice that makes him embarrassed. What is more, it is a way of getting rid of the reality. As the time goes, he has a nameless horror of the man.

The character of Hester Prynne also can reflect Arthur Dimmesdale's cowardice. As a woman, she bears alone the stigma in order to protect Arthur Dimmesdale. She replies "never", although Mr. Wilson questions her in a harsh voice on the day when she is put on the marketplace. After knowing Arthur Dimmesdale's health is getting worse and worse, Hester comes to negotiate with Roger Chillingworth, hoping to get Arthur Dimmesdale released from Roger Chillingworth. She persuades Roger Chillingworth that it was herself, not less than him. Even more she dares to fight with Roger Chillingworth. Considering what is discussed above, it can be seen what a poor man Arthur Dimmesdale is. Comparing with Hester, a female, Arthur Dimmesdale is nothing but a weakling. Moreover, it is Hester on her initiative who is to meet Arthur Dimmesdale in order to solve the problem. In other words, it is him that compensates for his sin and renews his life. At this time, Hester becomes not only the lover of Arthur Dimmesdale but also the mother who gives love to her child. Hester advises that they should go back to the Old World. However, Arthur Dimmesdale refuses at last. Until now, Arthur Dimmesdale's cowardice comes to the climax.

\subsection{Evil Man Being Obdurate}

Arthur Dimmesdale's obduracy is mainly displayed in two ways. On one hand, Roger Chillingworth is an evil person standing beside him, but he has not realized that. More ironically, old Roger Chillingworth is considered as the medical adviser by the Reverend Mr. Dimmesdale at the begining. And this provides a way for Chillingworth to probe Arthur Dimmesdale's sin. On the other hand, Arthur Dimmesdale never wants to escape from the strict and cruel Puritanism. He is completely a fervent preacher. In Roger Chillingworth's view, he was a true preacher, and a true religionist. That means that he is deeply affected by the religion. His view and his life are connected with religion which is regarded as corrupt and obstinate. Arthur Dimmesdale treats Roger Chillingworth as the worst sinner in the world and readers could know how deeply Puritanism affects him. That is to say, Puritanism is branded in his heart. When Hester suggests that they should go back to the Old world, Arthur Dimmesdale refuses. He is so powerless that he cannot go. He dares not quit the post which Providence places him. Providence gives him the post and Providence contorts his soul and takes his life overwhelmingly.

\section{Factors of Shaping Arthur Dimmesdale's Double Personalities}

\subsection{Factor of Social Background}

Arthur Dimmesdale's double personalities have deep roots in his society since men are the central and overarching gender, which are empowered to act as God's mediators. In fact, men, not women, must be significant. In The Scarlet letter, Bellingham is the fit leader of the puritan community. And Arthur Dimmesdale is the representative character who is wise and virtuous. So his talent can be seen everywhere when he gives sermons. No one will be unmoved. From this, it is known that in the $17^{\text {th }}$ century, the society needed such a man, Arthur Dimmesdale, as the author tells, becomes an eminent man accelerating New England to a position which is the essential spirit and flower of that which is about to become uppermost in the mother country. However, in the 17th century, when public punishment was common in monarchical Europe, torture and execution had a political as well as a juridical function; they were ceremonials by means of which the power of the sovereign, injured in the commission of any crime, was seen to be constituted. In and on the body of the criminal, the sentence had to be legible for all at that time. This is Foucault's formulation, yet it can be considered as the whole society's point on the so-called crime. As the chosen person, Arthur Dimmesdale surely realizes that. The more knowledge he masters, the more he is frightened and thus he tries to mask his irresponsibility, cowardice and obduracy. Consequently, his double personalities are formed. 


\subsection{Factor of Author's Personality}

To some extent, Hawthorne's personality shapes the figure of Arthur Dimmesdale. Hawthorne, who lived in the middle nineteenth century, was deeply influenced by Puritanism, transcendentalism and skepticism. Born on July 4, 1804 in Salem, Massachusetts, Hawthorne was a descendant of a prominent puritan family. From this day on, the traditional custom and religion had a great effect on him and he felt very melancholy. His grandfather, as a judge of the Bay Colony in 1650's, condemned men and women to death in persecution of the Quakers. This historical event like an evil haunted over his soul all the time and shaped him into a person who had a somber and solitary attitude. He always doubted the hereditary "original sin" and the doctrine of Puritanism. He lived in the era of the Renaissance in America. Because of the prevalence of transcendentalism and skepticism, he began to probe the condition of human beings and fate. He came to realize that humanity was constrained and happiness was vandalized. And at the same time, he could not escape from the corrupt cultural customs. He sought to change his life style and pursued the ideal moral, but he got nowhere. He could not find the reasonable method to pull him out. Then, at this time, Hawthorne became a writer who was depressed, irresolute and stray. All his life, Hawthorne seemed to be haunted by his sense of sin and evil in life. Evil seemed to be man's birthmark and the blackness of vision which comes as a natural corollary has become his trade mark in him. To Hawthorne, sin would be punished in one way or another. Due to his multiple personality, his heroes would be nothing but branded multiple personalities. Arthur Dimmesdale, without any doubt, is the best example.

\subsection{Influence of Puritanism}

No matter how intelligent Arthur Dimmesdale is or no matter how irresponsible, cowardly and obdurate he is, he is branded with the features of Puritanism. Since the 17th century, Puritanism was prevalent in New England. A group of people thought that the Church of England was too Catholic and wanted to purify the church, hence the name "puritan". These puritans were Protestants who followed the doctrine preached by John Calvin. They believed that God was incomprehensible to man, and that the power of God was all-knowing, yet hidden and unknown to man. The Puritans were convinced that human beings were predestined by God before they were born (Zhu, 1998, p. 8). Some were God's chosen people while others were predestined to be damned to hell. The Puritans believed that everyone had a calling, which was given by God and the success of one's work or the prosperity in his calling was the sign of being God's election. Therefore, working hard and living a moral life were their ethics. How could puritans find God's will and establish a contact with God? They concluded that the Bible was the authority of their doctrine. So every puritan had to read the Bible in order to find God's will and search for one's individual contact with God. To be able to read the Bible and understand God's will, education was essential for the puritans. Arthur Dimmesdale is educated in one of the great English universities and became an excellent Minister. However, Puritan religious teaching tended to emphasize the image of a wrathful God. Puritans were in favor of power and authority. In the book, Hawthorne described that religion and law were almost identical. Both were so thoroughly inter-fused. As in another book, Hawthorne had the descriptiong of the Puritans as the stern and black-browed followers. As God's chosen person, Arthur Dimmesdale knew power and authority more than other people. In front of his people, he was the servant of God. He knew his master's will. What was more, he clearly knew the punishment of his master - an adulterer should wear a letter " $A$ " and a letter " $\mathrm{T}$ ' should be branded on the brain of a thief and " $\mathrm{D}$ " be hung on the body of a "drunkard", etc. Arthur Dimmesdale was scared. He tried to hide his sin in order to escape from the punishment. The harder he tried, the more he was frightened. Literally, he could not get rid of his Puritanism. Thus, it shaped the other side of his personality-irresponsibility, cowardice and obduracy. In the end, Arthur Dimmesdale became the victim of a terrible fascination with his quest for mortality and corruption and Arthur Dimmesdale's mind was restrained and his soul was contorted.

\section{Conclusion}

Arthur Dimmesdale's genius overwhelmed people's every nook and every corner. All kinds of people, from Good Mr. Wilson to the prisoners; from Hester Prynne to Roger Chillingworth, were nothing but attracted and moved by Arthur Dimmesdale's sermons, his tremulously sweet, plain voice. The voice uttered from his deep heart and was given for the sake of Providence. He, as the servant of Providence, cultivated his people and urged and inspired them to the way of the pilgrim. Honesty, thrift and the maintenance of authority became their goals and their dreams and haunt over their lives. Arthur Dimmesdale was nothing but a genius.

However, his genius cannot veil his irresponsibility, cowardice and obduracy. Moreover, it deepened his irresponsibility, cowardice and obduracy. To Hester, being a lover, he had not undertaken his duty of a husband; to Pearl, he had not fulfilled the obligation of a father; to himself, he was not the man who he was! In other words, he was a liar, even a loser. His cowardice hurt not only himself but also Hester and Pearl. His cowardice 
took away his life. For his obduracy, he became the victim and yet he died by his own hand.

In a deep sense, Hawthorne criticized the corrupt society and the veil of Puritanism. He strongly attacked the devilish side of Puritanism, which restrained people's minds, distorted their souls and took their lives. Arthur Dimmesdale was one of them who was born in such a distorting society and death was his final fate without any doubt.

\section{References}

Cao, F. (1994). The Preface and the Style of the Novel. Tianjin: Tian Jin University Press.

Chang, Y. (2003). A Survey of American Literature. Nankai: Nan kai University Press.

Wu, W. (1990). History and Anthology of American Literature. Beijing: Foreign Language Teaching and Research Press.

Zhu, Y. (1998). The Society and Culture of Major English-Speaking Countries. Beijing: Higher Education Press.

\section{Copyrights}

Copyright for this article is retained by the author, with first publication rights granted to the journal.

This is an open-access article distributed under the terms and conditions of the Creative Commons Attribution license (http://creativecommons.org/licenses/by/4.0/). 